hope that her interest in keeping it up to date will continue through many more revisions.

In the absence of guides to the public documents of other nations and of international organizations as easily accessible and as comprehensive as Boyd's United States Government Publications, librarians will find Brown's Manual of Government Publications very useful. The author, a professor of Political Science at the University of Michigan, has designed his handbook for the use of research workers or those interested in politics and it emphasizes tools for locating publications of use to these groups.

Of the 17 chapters, nine are devoted to the United States, the ninth covering publications of state, municipal and local units of government-the great uncharted wilderness of our public documents domain. Four chapters cover Great Britain and the British Com- monwealth of Nations; one chapter covers Europe, including France, Germany, Austria, Soviet Russia, Italy and Ireland; and another single chapter is allotted to Latin America, the Near and Middle East, Japan and China. The international organizations whose publications are discussed are the League of $\mathrm{Na}$ tions, the Permanent Court of International Justice, the International Court of Justice and the United Nations.

Obviously, in a handbook so slim as this with a scope so wide, only a few of the major series of publications can be mentioned specificaliy. Most of the references are to other bibliographic guides, but since these are frequently difficult to locate readily this little handbook will be a very welcome addition to librarians as well as to political scientists.Margaret E. Egan, Graduate Library School, University of Chicago.

\title{
Old and New Scientific Works
}

A Catalogue of Incunabula and Manuscripts in the Army Medical Library. By Dorothy M. Schullian and Francis E. Sommer. Published for The Honorary Consultants to the Army Medical Library by Henry Schuman, Inc. New York, 1950, 361p. $\$ 15$.

Scientific, Medical and Technical Books, Published in the United States of America. A Selected List of Titles in Print with Annotations. Supplement of Books published 1945-1948. Edited by R. R. Hawkins. Prepared under the direction of the $\mathrm{Na}$ tional Research Council's Committee on Bibliography of American Scientific and Technical Books. Washington (N.Y., R. R. Bowker Co.), 1950, 526p. \$10.

Here is a new reference tool for the historian of science, and for those interested in fifteenth century books. It occupies a welldeserved place beside its illustrious predecessors in this field, Klebs, Osler, Sudhoff and Ballard.

A Catalogue of Incunabula and Manuscripts in the Army Medical Library represents another example of the superb bibliographic enterprises which we have come to expect from our National Medical Library. Instructors in the graphic arts will be happy to learn that lantern slides have been made of historically significant illustrations, title pages, printers' marks and other materials suitable for lectures based on the collection. The record of incunabula is of particular interest to scholars and librarians, for each has been microfilmed and is available for loan in that form.

Young scholars in the history of science and civilization, following in the footsteps of Sarton and Thorndike, will have accessibility denied to their predecessors. It is a pious hope that the disciples will utilize the material.

The incunabula portion of the work is equipped with two concordances, Klebs and Stillwell. In addition, there is a general index of printers, places, owners, incidental names, variant forms of author names and dates.

This volume has also a record of the western manuscripts in possession of the library. Part 2 of the work contains a record of their oriental manuscripts, predominantly Arabic. An index of names and titles enhances the checklist.

This volume is one which every American library boasting a Rare Book Room will wish to have on its reference shelf. Printed by the Anthoensen Press, published by Schuman for the Honorary Consultants to the Army Medical Library, the volume is a fine example of book making. 
The Hawkins work is the long awaited supplement to the base volume which covered the period, r930-1944. The purpose of the work is to supply descriptions of the outstanding scientific, medical and technical books written by citizens of the United States and Canada, published in the United States during the years 1945-1948. Citations are given for about 2600 books.

The subject scope is indicated in the title, but there are certain exceptions. The social sciences are omitted, except for certain works in such fields as nursing and psychology, where some books which are listed are equally useful for sociological and technical information. The selections on a given subject are intended to represent the books that would be available in a well-stocked American library with an active collection in that subject. The list is one of important and useful books, rather than a list of "best" books. This publication and the one which it supplements is a "must" for the general reference collection in any college or university, and an "absolute must" for every science library.Thomas P. Fleming, Columbia University.

\section{Peter Schoeffer}

Peter Schoeffer of Gernsheim and Mainz, with a List of His Surviving Books and Broadsides. By Hellmut Lehmann-Haupt. Rochester, N.Y., Leo Hart, 1950, 146p. \$5.00. (No. 4 of the Printers' Valhalla series, edited by George Parker Winship.)

Three names stand out in the story of the beginning of printing at Mainz: Gutenberg, the inventor; Fust, the financier; and Schoeffer, the artist and craftsman. Schoeffer, the young assistant of Gutenberg and later, the son-in-law of Fust, is the subject of this attractive and surprisingly interesting monograph by Dr. Lehmann-Haupt.

Probably a student (possibly of law) at the Sorbonne in 1449 , he worked there as a calligrapher and a manuscript copyist. From Paris he went to Mainz, which is close to Gernsheim, his home, and became an assistant to Gutenberg. But at the famous trial on Nov. 6, 1455, Schoeffer testified in favor of Fust who, awarded the decision, took away most of the inventor's printing materials.

Next, we find Schoeffer operating a press, first with Fust, then by himself. His experience as a calligrapher, the evidence shows, aided him to become an excellent typecutter and book-designer. The beauty of his books has aroused the admiration of bookmen for nearly five centuries.

It was but gradually that Peter Schoeffer broke away from his first practice of making his printed books follow the artistic standards of the manuscript. In these his earliest productions Schoeffer's difficult color printingwhether or not we accept the reconstruction by Rudolph Ruzicka and by Heinrich Wallau (p.40-45) of its method-involved great technical problems. But slowly experience taught Schoeffer to think of typography as a new art, of the use of contrasting black and white, aided, when the individual purchaser of the book desired it, by color added by the rubricator.

Again, Schoeffer printed law books with their texts on balanced pages surrounded by commentary which referred to the pages enclosed. Schoeffer, to be sure, could print from a manuscript which had the commentary surrounding the text and could abbreviate or expand the spelling of his legal Latin copy-an expedient probably more easily employed than those suggested (p.48-49). Nevertheles; this was a typographical feat requiring skill.

Schoeffer was a clever and successful business man who sold the books which he printed. Aided by an approximately complete unpublished list of surviving Schoeffer imprints compiled by the Gesamtkatalog staff, which he obtained while serving with the U.S. Military Government in Germany, Dr. LehmannHaupt is able to show how varied were his productions. Most bookmen know Schoeffer as a printer of stately missals and Bibles. But Schoeffer printed not only a considerable amount of theology and law, the classics and other serious works, but also a cookbook and a calendar. $\mathrm{He}$ also produced numerous items of job printing - the bulls of popes, proclamations of the emperor, letters of the warring claimants to the archdiocese of Mainz, indulgences, propoganda pieces against the Turks and even the announcement of a sporting event of a municipally conducted crossbow tournament.

Schoeffer, like a good business man, ad- 